\title{
Kamusal Alanda Sanat ve Sanat Eserleri
}

\section{Art and Art Works in Public Sphere}

\author{
Dr. Öğr. Üyesi Hülya PARLAKKALAY (D) 1
}

$\ddot{\mathbf{O} z}$

İnsanın yaşadığı evreni yaratıcı bir bakış ile algılama ve tanımlama çabasının odak noktasında yer alan sanatsal eylemler, aynı zamanda bilgi alışverişine dayalı toplumsal bir iletişim ve sosyal bütünleşme alanı olarak toplumların kültürel gelişimlerini beslemektedir. Bu bağlamda çalışma, sanatın eserler aracılığıyla kamusal alanlar ve mekanlarda yer alması, yaygınlaşması ve alımlayıcı ile etkileşim içinde olması ile ortaya çıkan olumlu kültürel dönüşümün etkilerini orataya çıkarmayı hedeflemektedir. 21. yüzyıl ile kentsel gelişimin ivme kazanması, çağdaş düşün ve sanat biçimlerinin kamusal alanlarda toplumla buluşturulması ve izleyicisi ile etkileşime geçmesi toplumun gelişimi açısından önemli dinamikler oluşturmaktadır. Sanatın kitlelerle buluşturulması, sanatın toplumsal alanda yaygınlaştırılmasına katkı sağlamakta, bu katkı kent dokusunda gözlemlenen olumlu dönüşümler ile sosyal ilişkilerin yapısının iyileşmesinde ortaya çıkmaktadır. Sanatsal etkinlikler, sanatsal kaygıların ve aktarılan düşüncenin yanı sıra birey üzerindeki etkisi ve oynadığı rol bakımından da önemlidir. Bireyler bu etkileşim sürecine dahil olmaktadırlar. Kamusal sanat, kamusal diyaloğu ve farkındalığı artırmakta ayrıca demokratik bir paylaşım alanı yaratmaktadır. Bu kapsamda kentsel gelişim ivmesinde çağdaş düşün ve sanat biçimlerinin toplu kullanım mekanlarında toplumla buluşturulması çağsal dönüşümün eşiğinde büyük önem taşımaktadır. Ekonomik ve politik merkezler olma hedefini çizen yeni kentsel politikalar, nüfusun kentsel alanlarda yoğunlaşmasına neden olduğu gibi, kentlerin sanat etkinliklerine olan ilgisini artırmaktadır. Sanatsal etkinlikler, ulusal alanda olduğu kadar uluslararası arenada kente politik ve kültürel bir statü kazandırmaktadır.

Anahtar Kelimeler: Sanat, kamusal sanat, kamusal alan, mekan, erişim

Makale Türü: Araştırma

\begin{abstract}
Artistic activities, which are the focus of the effort to perceive and define the universe in which human beings live by creative perspective, also feed the cultural development of societies as a social communication and social integration area based on information exchange. In this context, the study aims to find out the effects of the positive cultural transformation that occurs with taking part of art in public sphere and spaces through artworks, its spread and interaction with the receptive. The acceleration of urban development with the 21 st century, the introduction of contemporary ideas and art forms with the society in the public sphere, and the interaction with its audience constitute important dynamics for the development of the society. Bringing art together with masses contributes to the popularization of art in the social sphere, and this contribution appears in the improvement of the structure of social relations with the positive transformations observed in the urban pattern. Artistic activities are important in terms of artistic concerns and conveying of thoughts, as well as their impact on the individual and the role they play. Individuals are involved in this interaction process. Public art raises public dialogue and awareness as well as creates a democratic space for sharing. Within this scope, throughout the urbanization pace, bringing contemporary philosophical and art objects together with the society in the public areas in the edge of epochal transformation has great significance. The new urban policies claiming to be economic and politic centers caused the population to concentrate around urban areas, it raises urban interest toward art activities. Artistic activities add political and cultural status to the city in terms of both national and international arena.
\end{abstract}

\footnotetext{
${ }^{1}$ Afyon Kocatepe Üniversitesi, Güzel Sanatlar Fakültesi, hulas@aku.edu.tr.

Atıf için (to cite): Parlakkalay, H. (2020). Kamusal alanda sanat ve sanat eserleri. Afyon Kocatepe Üniversitesi Sosyal Bilimler Dergisi, 22(4), 1157-1172.
} 
Keywords: Art, public art, public sphere, space, access

Paper Type: Research

\section{Giriş}

Her birey düşünsel ve eylemsel etkinlikleriyle kültürel oluşumun yaratıcılarıdır. İnsanoğlu tarafından yaratılan kültür, aynı zamanda insanı şekillendiren en etkin öğedir. Bu karşılıklı etkileşimde hiç kuşkusuz sanatın diğer kültürel öğelerden farklı ve ayrıcalıklı bir yeri bulunmaktadır. Kültürün temel öğesi olan sanat, toplumların kültürel kimliklerini oluşturduğu gibi, toplumsal yaşama katkıda bulunur. Bu nedenle sanatın kamusal alanlarda ve mekanlarda yaygınlaşması, yaşayan bir organizma olan kültürel gelişimin sürdürülebiliği için de en önemli etmenlerden bir tanesidir.

İnsan yaşadığı evreni yaratıcı yönden kavrama ve tanımlama çabasında temellenen sanatsal eylem, aynı zamanda bilgi alışverişine dayalı toplumsal bir iletişim ve sosyal bütünleşme alanı olarak toplumların kültürel gelişimlerini beslemektedir.

Kentsel yaşamın M.Ö. 3500 yıllarına kadar uzandığı, Neolitik Dönemde politik yapıların doğuşu ve gelişimiyle aynı döneme rastladığı tahmin edilmektedir (Pustu, 2006, s. 129). Fakat kentleşme esas anlamıyla sanayi devrimi sonrasında teknolojik devrimlere ve ekonomik gelişmeye paralel ortaya çıkan bir olgudur. Endüstri Devrimiyle dönüşüm yaşayan insanoğlu günümüzde Bilişim Devrimi'ni yaşamaktadır. Bu kapsamda kentsel gelişim ivmesinde çağdaş düşün ve sanat biçimlerinin kamusal alanlarda toplumla buluşturulması, büyük önem taşımaktadır. Ayrıca, ekonomik ve politik merkez olma hedefini çizen yeni kentsel politikalar, nüfusun kentsel alanlarda yoğunlaşmasına neden olduğu gibi, kentlerin sanatsal etkinliklere olan ilgisini artırmaktadır.

Kamusal alanda gerçekleştirilmiş olan sanat eserleri ve tasarımların mekanlarda kişiler arası iletişimi ve insan-çevre etkileşimini olumlu yönde etkilemesi bağlamında önemli bir rol oynadığı görülmektedir. Kamusal alanlarda sanat eserinin var oluşu ile bireyler kamusal mekanları daha verimli kullanmakta ve mekanlarda daha üretken ve mutlu olmaktadırlar. $\mathrm{Bu}$ mekanlarda sanat ve tasarım uygulamaları ile kamusal iletişim güçlenmekte, mekan estetiği artmakta ve görsel iletişimin sağladığı psikolojik rahatlama sağlanmaktadır.

Sanatın kitlelerle buluşturulması, sanatın toplumsal alanda yaygınlaşmasında, kent dokusunda kültürel dönüşümler ile sosyal yapısının iyileşmesinde önemli bir unsurdur. $\mathrm{Bu}$ unsurun, yani bilimin, tekniğin, sanatın, kültürün yaygınlaştııılmasında; üniversiteler, sanat kurumları, sanatsal organizasyonlar, bienaller önemli misyonlar taşımaktadır. Kültürel iletişimin aracı olarak gerçekleşen sanatsal ve kültürel etkinlikler, sosyal gelişime ve toplumsal aydınlanmaya katkı sağlamakta, kentin sosyal yaşamını gelişime açık ve dinamik yaşamsal ortamlar haline getirmektedir. Bu bağlamda bu çalışma ile kent dokusunu bir çok açıdan etkileyen, dönüştüren sanatsal projelerin, sanatsal tasarım ve uygulamaların demokratik kamusal alanlar oluşturmadaki rolü ve önemi araştırılmıştır.

\section{Yöntem}

$\mathrm{Bu}$ çalışmada kamusal alanda sanat eserlerinin birey ve toplum üzerindeki etkisinin incelenmesi ve yeni biçimsel ifade olanaklarının araştırılması amaçlanmakta ve kamusal alan kültürünü geliştirecek bir estetik kültürü geliştirmenin yöntemleri kamusal alan bağlamında ele alınmıştır. Araştırmanın genel amaçları doğrultusunda; sanat-kültür-toplum-kent ilişkisi, kamusal alanda sanat eserinin yeri ve önemini ortaya koyan ulusal ve uluslararası literatür, çeşitli kurumsal ve bireysel/sanatçı etkinlikleri, yazılı ve görsel kaynaklar, yapılmış bilimsel araştırmalar incelenmiştir. Sanat yapıtları, kamusal alanlarda bireysel çabalara oranla daha etkin bir tüketim sürecine girdiği için medya taraması yapılmış ve basında çıkan haberlere, haberler 
doğrultusunda etkinliğin yayılma alanı ve izlenme oranlarına da yer verilmiştir. Araştırmada elde edilen bilgiler ışığında, kamusal alanda sanat eseri; paylaşım, katılım, etkileşim ve iletişim süreci yaratarak toplumsal sorumluluğun temellerini oluşturmaktadır. $\mathrm{Bu}$ bağlamda çeşitli ülkelerde, şehirlerde ve kamusal alanlarda, gerçekleştirilmiş kamusal sanat eserleri tespit edilerek bu eser ve sanatçılar üzerinden araştırmalar gerçekleştirilmiştir. Araştırmada yer alan eser ve sanatçılar dünya üzerinde bu alanda izleyici üzerinde güçlü etkiler elde eden sanatçılar/eserler olarak ele alınmış ve eserler ilgili literatür ışığında tartışılmıştır. Bunlara ek olarak, disiplinlerarası bir yaklaşımla kamusal alanda sanat eserleri, toplumsal duyarlılıkların, kamusal diyaloğun ve farkındalıkların gelişimine önemli katkılar sunarak demokratik bir paylaşım alanı yaratmaktadır. Araştırma sonunda elde edilen veriler doğrultusunda, eserlerin birey ve toplum üzerinde oluşturduğu etki ve sonuçlarının toplumu nasıl dönüştürdüğü, ilgili literatür doğrultusunda değerlendirilmiş ve tartışılmıştır.

\section{Kültürel Varlık Olarak Sanat}

Yeni kültürel değerleri üreten ve taşıyan sanatsal etkinlikler, kentin sosyal-toplumsal yapısını olumlu yönden etkilemesi bakımından büyük önem taşımaktadır. Toplum sadece bireylerin oluşturduğu bir topluluk olarak algılanamayacağı gibi, kentleşme kavramı olarak sadece kent nüfusundaki artış anlamına gelmemektedir.

Tunalı'nın belirttiği gibi, “insanın toplumsallaşmasıyla, özgürleşmesiyle, doğa üzerinde insanın yarattığı yeni bir varlık doğar. Bu varlık kültür varlığıdır. Bu kültür varlığının temelini ise insan ilişkileri oluşturmaktadır'(Tunalı, 1996). Bireysel ilişkilerin belirlediği kültürel kişilik, kentsel dokuyu belirler, bu bağlamda kent kültürü, kentte yaşayan bireylerin ortak benliğini, kültürünü ve kimliğini yansıtmaktadır. $\mathrm{Bu}$ nedenle, kentlerin kimliğini belirleyen kültürel örgüde, toplumsal kurumların karşılıklı iletişimine dayalı kültür-sanat etkinlikleri, toplumsal gereksinimleri karşılamakla beraber, kentsel yaşamın kültür birikimini oluşturmaktadır. Kamusal alanda ortaya çıkarılan bu kültürel birikim aynı zamanda toplumların sanatsal kimliklerini oluşturduğu gibi, toplumsal yaşama katkıda bulunmaktadır.

\section{Kent ve Kamusal Alan İlişkisi}

\subsection{Kent Kavramı}

Kentler, kendisine özgü öğeleriyle kimlik bulurlar. Kendine özgü tarihsel, kültürel veya coğrafi nitelikler taşıyan kamusal alanlar, kentleri yaşam alanlarına çeviren en önemli unsurlardandır. Kent, insan topluluklarının mekânlarda yaşam alanları oluşturmaları sonucunda ortaya çıkmış bir olgudur ve olgusal açıdan bakıldığında kamusal alanlarda bulunan eserleri, kentlerin belleğinde önemli yer tutan metaforlar olarak görmek mümkündür. Kentlerin, meydanların ve özellikle yayalara ayrılmış mekanların kendilerine özgü kültürel değerlerin oluşumuna en büyük katkı, kamusal alanda sanat eserlerinden kaynaklanmaktadır.

Kent üzerine yapılan çalışmalarda ortaya çıkan en önemli nokta, dünyada bulunan kent sayısı kadar da kent tanımının yapışabileceği gerçeğidir. Bu bağlamda kısa bir tanım yapacak olursak: "Öncelikle kent yabancıların bir araya geldiği insani bir yerleşim yeridir. Bu tanımın doğru sayılabilmesi için yerleşimin geniş, heterojen bir nüfusu olmalı, insanlar arası piyasa mübadelesi bu yoğun ve heterojen yığının birbiriyle etkileşimini sağlamalıdır" (Sennett, 2002, s. $62)$.

\subsection{Kamusal Alan Kavramı}

Kamusal alan terimi, toplumbilim ve dilbilimci Jürgen Habermas'ın Kamusal Alanın Yapısal Dönüşümü adlı kitabı ile sosyal bilimler alanına girmiştir. Günümüz akademik çalışmalarda sıkça üzerinde durulan bir kavram olmuştur (Habermas, 1962). Habermas'a göre kamusal alan, tüm toplumu etkileyen problemleri 'algılama, teşhis etme ve iyileştirme' arenasıdır (Habermas, 1962, 1996, s. 359-373), çağdaş medya, siyaset çalışmaları için de popüler terimlerden birisidir (Keane, 2002, s. 295; İrvan, 2002, s. 293). 
Kamusal alan kavramının birbirini tamamlayan, olgusal ve genel olarak iki boyutu vardır. Birinci boyutuyla kamusal alan, modern kamu hukukuyla tanımlanmış fiziksel mekandır. Resmi daireler, okullar, hastaneler, meydanlar, parklar gibi halkın ortak kullanımına açı her türlü kent mekanı kamusaldır. Kamusal alan, ikinci boyutuyla standart bir ilkeyi, bir ideali belirtir; "ortak, aleni, açık olan" anlamına gelir ve çoğunluğu kapsayan bir yapıya sahiptir. Kamusal alanın en önemli özelliği tüm halka açık olmasıdır. "Kamusal alan, sosyal ve politik sorunların çözümü amacıyla kişilerarasında değerler ve ölçütler üzerinde anlaşmaya varılma imkanının bulunduğu yaşam alanıdır" (Mutlu, 2004, s.164).

Kamusal alanlar, sosyal yaşam akışı içinde düşüncelerin, ifade biçimlerinin ve deneyimlerin oluştuğu, paylaşıldığ birlikte oluşan kültürel, sanatsal ve toplumsal deneyim sonucu, kamusal sanat kamusal kültürün yaratıcısıdır. Kamusal alan, demokratik edinimlerin gerçekleşebildiği bir kent mekânı olarak düşünülmektedir. "Kültürü meta biçimine getiren ve onu tartış1lmaya uygun bir yapıya dönüştüren kamusal topluluk, dışa kapalı olmayan bir nitelik kazanmaktadır " (Habermas, 2003, s.107).

Toplumun, siyasal ve ekonomik hayatta içinde kendini ifade edebilmesi için kamusal alanın yaşayan bir organizma olarak aktif olması, bazı durumlarda ise yeniden yaratılması gerekir. Bu bağlamda kent içinde kamusal alanlar oluşturmak beraberinde düşünsel, toplumsal, psikolojik sorunlara da yönelik yeni çözümler ortaya koymayı gerektirmektedir. Bu çözüm yollarından en etkili olanı da sanattır.

\subsection{Kamusal Mekan}

Kamusal mekanlar, kentte yaşayan bireylerin iletişim kurduğu, çeşitli etkinlik ve aktiviteleri gerçekleştirdiği kapalı ve açık mekan olarak kentin ve toplumun şekillendiği alanlardır. Toplumdaki her bireyin yaşam alanına açık olan yollar, meydanlar, parklar, dini mekanlar, hastanelere kadar kamuya açık olan açık-kapalı bütün mekanlardır. Kamusal alanlar, mekanlar bireylerin birbirleri ile karşılıklı iletişim kurdukları ortak kullanım alanları olarak da tanımlanabilir.

\section{Kamusal Sanat, Türkiye ve Dünyada Kamusal Sanat Örnekleri ve Eser İncelemeleri}

Günümüz insanı kent yaşamının sıradan döngüsü içinde giderek kendine yabancılaşmış ve doğadan uzaklaşmış bir yaşam biçimi ile sarılmış durumdadır. Özellikle bireylerin metropollerde hapsedilmiş kitleler halindeki yaşam biçimlerinin değiştirilebilmesi ve duyarlılıklarını, farkındalıklarını yeniden kazanabilmesi sanatın, sanatsal üretimlerin günlük yaşama ve yaşam alanlarına girmesi ile mümkün olacaktır. Müzeler ve sanat galerileri arasında sıkışmış sanat eserlerinin, geniş izleyici kitleleriyle etkileşime geçebileceği kamusal alanlarda varlık göstermesi üç noktada önem kazanmaktadır. Sanat eserlerinin sergilendiği mekanlar, sanatçı ve sanat izleyici üçgeninde, sanatın bütün dinamikleri açısından geliştirici bir niteliğe sahiptir. Bu bakış açısı ile kent, içinde yaşayan insanlar için üretken ve dinamik bir yaşam alanı haline gelmektedir. Böylece mekanla ilgili algılarda olumlu bir farkındalık yaratma olasılı̆̆ gerçekleşebilmektedir.

Bunun en güzel örneğini 2015 y1lında İstanbul'da gerçekleşen 14. İstanbul Bienali'nde görmekteyiz, Avrupa, Asya, Afrika, Avustralya, , Ortadoğu, Latin Amerika ve Kuzey Amerika'dan bir çok katılımcı sanatçının çalışmaları Boğaz'ın Avrupa ve Anadolu yakasında bulunan birbirinden farklı özelliklere sahip otuzdan fazla mekanda izleyici ile buluşmuştur. "Tuzlu Su" kavramından yola çıkan bu bienal bir çok sanatsal kurumun yanı sıra deniz kıyısında, teknelerde, eski tarihi mekanlarda, parklarda ve su üzerinde geçici olarak kurulan alanlarda gerçekleştirilerek bütün şehir sergi mekanı haline getirilmiştir. Bienal farklı mekanlarda kente yayılacak biçimde planlanarak izleyicilerine ulaşmıştır. Ayrıca bienal 545.000 izleyeni ile on iki hafta boyunca halka açılmıştır (NTV, 2015). 
Şekil 1. Adrian Villar Rojas, Tüm Annelerin En Güzeli, Troçki Evi, 2015, Büyükada, İstanbul.

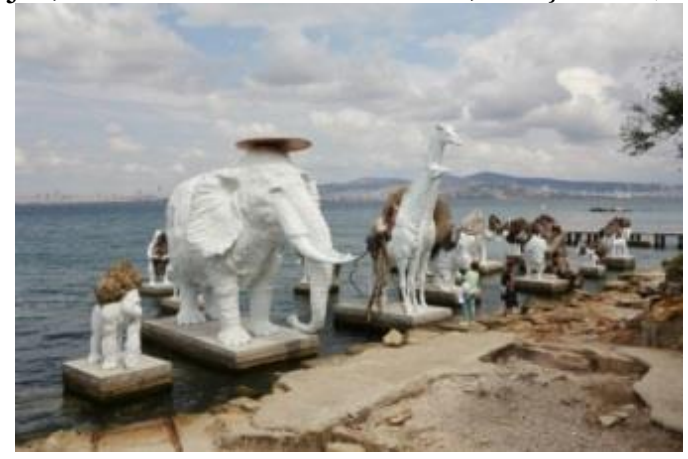

Kaynak: URL-1

Kamusal alanlarda sanat eserleri ve sanatsal etkinlikler, doğayı sanat aracılığı ile insana yaklaştırmakta ve kenti çelik, cam yığını haline gelmiş olan mekanların soğukluğundan kurtarmaktadır. İnsanlara, kentin günlük yaşam akışından farklı olarak, zihinsel rahatlama noktaları yaratmakta, zıtlıklar ve algısal yanılsamalar ile bireylere şaşırtıcı, merak uyandıran sürprizlerle karşılaşma imkanları sunmaktadır. Günümüzde kamusal alanlarda yapılan sanat uygulamaları ile insan fantastik, masalsı ifadelerle karşılaşmakta, sanatla hiçbir ilgisi olmayan insanların günlük hayatta sanatla, bir sanat eseriyle iletişimi sağlanmaktadır. Başka bir deyişle sanatın müze ve galerilerden çıkarak insanlarla iletişime geçmesine olanak sunmaktadır (Şekil $1)$.

Kamusal sanat, insanı zihinsel çağrışımlara açık ve mekânla insanın ilişkisini yeniden düzenleyen, olumlu anlamda farklılaştıran bir yapıya sahiptir. Kamusal sanat eserleri, insanı sanat etkinliklerine katılmaya teşvik ederek, içinde bulunulan mekanları pozitif olarak etkiler ve kamusal mekanların sahiplenilmesine gerçek anlamda yaşanılır mekanlar olmasına olanak sağlamaktadır. Toplumsal odaklı sanat etkinlikleri, kamusal mekanın kolay erişilebilirliğini öne çıkararak aynı zamanda sanat eserinin oluşum sürecinde bireylerin katılımını da sağlamaktadır. Kamusal sanat, insanların farklı yaşamsal deneyimler kazanmalarını desteklemekte, toplumun kültürel yaşamında önemli bir dinamiktir olarak kendisini göstermektedir. Kamusal sanat ile elde edilen en önemli değerlerin başında bireylerin karş1lıklı anlayış, hoşgörü ve saygı çerçevesinde demokratik ve barış temelli bir toplumunun oluşmasına katkı süreci gelmektedir. Toplum tarafından sanata verilen değerin artması, sanatın toplumun bütün bireyleri için ulaşılabilir olması da diğer bir unsurdur. Sanatçı ve sanat eserlerin çağlarının tanıkları olduğu düşüncesi ile sanat tarihine baktığımızda ve bugün klasik olarak değerlendirilen eserler dikkate alındığında, o eserlerin dönemlerinin sosyal-kültürel ve tarihsel değerlerini, estetik anlayışlarını en güçlü şekilde yansıttıkları görülmektedir. Sanatçı, yaşadığı toplumun bir üyesi olarak eserlerini gerçekleştirirken içinde yaşadığı topluma yakın ve dikkatli bir bakış açısı ile bakmakta, toplumun o çağdaki aynası olmaktadır. Bu bağlamda sanatçı ile geniş kitlelerin etkileşimine ve bütünleşmesine en güzel olanağı kamusal alan sanat etkinlikleri sağlamaktadır.

Kamusal sanat, kent mekanlarında estetik değerlerin korunması, yaygın hale gelmesi, geliştirilmesi ve bireylerin iletişimini geliştiren bir araç olarak da görülebilir. İnsanların mekanları kullanma ve algılama biçimlerinde estetik bir hazın ortaya çıktığını da ifade edebiliriz. Bu yaklaşım ile kamusal mekanlar, mevcut durumlarının estetik kaygılarla ile yeniden düzenlenerek toplumla buluşturulmasını sağlamaktadır. Sanatçı ile etkileşimi sağlanan izleyicilerde doğal olarak estetik beğeni düzeyi ve sanata yaklaşımları noktasındaki farkındalıklarının arttığı gözlemlenmektedir. $\mathrm{Bu}$ durum sıklıkla insanların yaya olarak bulunduğu mekanlarda görsel etkileşimin yol açtığı, mekan estetiğinin gelişimini, kültürel doyumu, çevre bilinci ve toplumsal huzuru beraberinde getirmektedir.

Kamusal sanat son yıllarda mekan kimliğine yönelik kentsel dönüşüm projelerinin temel noktası olarak görülmektedir. $\mathrm{Bu}$ tarz projelerin uygulandığı kentlerin bilinirlik düzeylerinde artış görülmüştür. Sanat eserleri aracılığ $\breve{g}_{1}$ ile kentler yeniden tanımlanabilmektedir. 
Hindistan asıllı sanatçı Anish Kapoor'ın insanları bulutlarla birleştiren "Bulut Kapısı" isimli dev heykeli Chicago kentinin sembolü haline gelmiştir. Ayrıca eser Amerika'nın önemli on sembolü arasına girmiştir. $\mathrm{Bu}$ örnekte olduğu gibi eser bulunduğu alanın özelliklerini bünyesinde taşımakta ve izleyiciyi içine çekmekte, izleyicisi ile etkileşim içinde bir anlam kazanmaktadır (Şekil 2).

Şekil 2. Anish Kapoor, Bulut Kapısı, 2004, 100 ton ağırlı̆̆ında çelik, Chicago, ABD

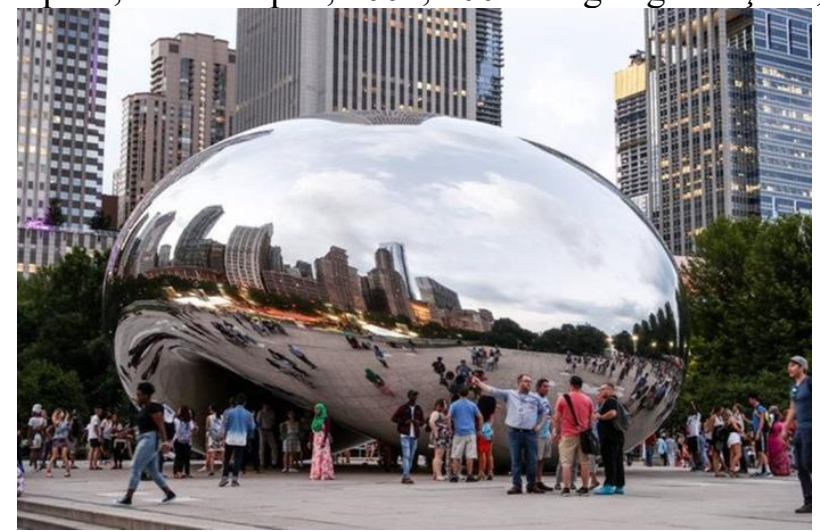

Kaynak: URL-2

"Bulut Kapısı" adlı eserin sergilendiği mekan toplumsal etkinlik alanında, kentin merkezinde ve herkesin eseri görebileceği ve etkileşime girebileceği bir biçimde sergilenmektedir.

Habermas da ortak toplumsal etkinlik alanların önemini şu şekilde ifade etmiştir: "Kamusal alan, modern toplum kuramlarında, toplumun ortak yararını belirlemeye ve gerçekleştirmeye yönelik düşünce, söylem ve eylemlerin üretildiği ve geliştirildiği ortak toplumsal etkinlik alanına işaret etmek için kullanılan kavramdır" (Habermas, 2003, s. 96).

Habermas'ın kamusal alanı tanımlaması doğrultusunda Kapoor eseri ile etkileşime giren kentli insanları, düşünmeye, sorgulamaya ve sürekli değişen bir estetik algının içinde olmaya teşvik etmektedir. Eserler, mekansal algıların değişimi kadar, kent yaşamı içinde gökyüzüne bakmayı unutan insanların yaşamsal alışkanlıklarının değişimi içinde önemlidir. Bu bağlamda kent kültürüne ivme kazandıracak estetik değerler, çok sayıda bireyin sanat eserlerine ulaşabilmesi ile gerçekleşecektir. Sanat eserleri kamusal alanlarda daha etkin bir biçimde izlenebilmektedir. Günümüzde sanatın, modern yaklaşımların ötesine geçerek daha dinamik ve yaşamla iç içe olmayı tercih ettiği görülmektedir. Günümüz sanatçları, eserlerini durağan bir yapıdan uzaklaştırarak, teknolojik gelişimle paralel bir biçimde yeni ifade biçimleri ortaya koymakta ve mekan ile olan ilişkisine yeni anlamlar yüklemektedir. Sanatı ve estetik değerleri sürekli yeniden kurarak günceli yakalama çabasında yeni kavramlar sunmaktadır. Kamusal bir kültür yaratmanın önceliği, kamusal mekanı biçimlendirmeyi ve kentin görsel biçimini yeniden inşa etmeyi gerektirmektedir. Kentin kendine özgü önemli sanat eserlerinin ve bunların sahip olduğu gösterge sistemleri onu dünya genelinde etkileşime sokan bir unsurdur.

Günümüzde büyük yankılar yaratan kamusal alanda sanat yapıtlarının geleneksel olanla bağlarını koparmış olduğunu ifade edebiliriz.

"Çağdaş sanatın en önemli açılımlarından birinin de, yapıtın galerilerde alınıp satılan bir meta olmanın ötesine geçmiş olmasıdır. Güncel sanat pratiklerinin, yapıtın da izleyicinin de biçimsel olarak tanımlanmamasının ve bir araya gelme alanı olarak kamusal alan kavrayışının da aynı şekilde maddi niteliklerden arındığını ve genişletildiğini de görmek mümkündür" (Sheilk, 2005, s. 80).

$\mathrm{Bu}$ açıdan bakıldığında günümüzde kamusal alanda sanat eserleri, evrensel bir kavrayışla sosyal ve kültürel bir gösterge olarak varlık kazanmaktadırlar. Kamu alanlarının sergi 
mekanlarına dönüşmesi eserlerinin kavramsal alt yapısı gereği olarak bir zorunluluk olarak düşünülebilir. Dünyanın birçok büyük kentinde kamusal alanlar, çağdaş sanatçılar için sanat platformu olarak işlev görmektedir. Geleceğin sanat mekanları kamusal alanın tümüne yayılma eğilimindedir.

Kent merkezlerinde ve meydanlarında tarihsel, kültürel veya siyasal temaları ile görmeye alışık olduğumuz anıtların toplum üzerinde güçlü etkileri göz önüne alındığında, bu etki günümüzde tümüyle devam etmese de çağdaş kamusal sanatının gelenekselleşmiş ihtişam ve yüceltme kavramından uzaklaşmakta olduğunu da gözlemlemekteyiz. Çağdaş kamusal alan sanatçıları bu gösterişli gösterilerden uzaklaşmakta daha güncel kavramalarla yola çıkabilmektedirler. Bu nedenle kamusal alan güncel sanat yapıtı için daha farklı çok katmanlı, eklektik ve etkileşimli bir zemin oluşturmaktadır. "Çağdaş sanatın güncel etkinlik sorunlarına yaklaşmak, soruna salt sanatçı birey açısından çözüm getirmeye çalışmak değil, kitle boyutunu da araştıran bir iş yapmaktır" (Tansuğ, 1982, s. 24).

Klasik ve alışılagelmiş estetik geleneklerin dişına çıkan Fransız fotoğrafçı ve sokak sanatçısı JR öncelikle "Inside Out" isimli çalışmaları ile tanınmaktadır. Dünyanın birçok ülkesindeki şehirlerde evlerin duvarlarına yerleştirdiği dev fotoğraflarla sanat yoluyla dünyanın çehresini değiştirmeyi hedeflemiş, JR yeni projesinde uğradığ 1 şehirlere İstanbul'u da dahil etmiştir. Sanatçı Berlin, Los Angeles, Havana ve Şangay gibi dünyanın dört bir yanındaki şehirlerde uyguladığı "The Wrinkles of the City" (Şehrin Kırışıklıkları) adlı proje kapsamında devasa ölçekteki siyah beyaz fotoğrafları özellikle eskimiş ve her an yıkılabilirmiş gibi görünen binaların duvarlarına yerleştirmiştir. Söz konusu fotoğraflarda yüzlerindeki kırışıklıkların da fark edilebildiği yaşlı bireyleri resmeden sanatçı bunları gönüllülerin de yardımıyla İstanbul'un Balat, Tarlabaşı ve Mahmutpaşa semtlerindeki binalara yapıştırmıştır. Sanatçı böylece, yaşlıların kişisel hikâyelerini sembolik bir şekilde duvarlara taşıyarak, şehir sakinlerinin kırışıklıklarıyla ve önceki nesillerin hikâyeleriyle yüzleşmesini amaçlamaktadır (Sanatblog, 2015).

Yaşlı kişilerin portreleri ile toplumsal yaşama kamusal alandan mesajlar veren sanatçı, etkin ve yoğun bir tüketim sürecini de başlatmış olmaktadır (Şekil 3 ve 4).

Şekil 3. JR. "The Wrinkles of the City” (Şehrin Kırışıklıkları) Balat, İstanbul

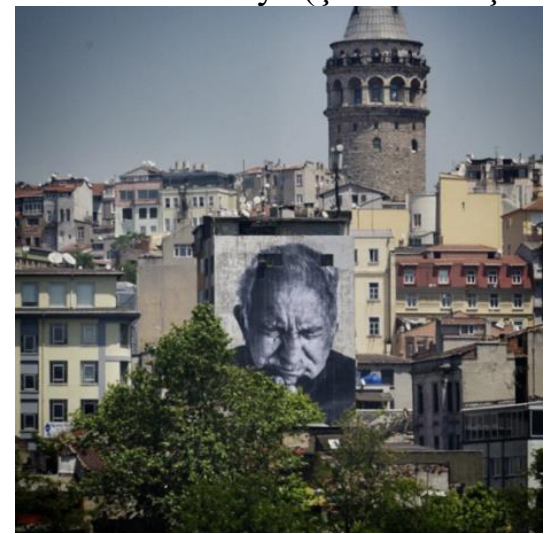

Kaynak: URL-3 
Şekil 4. JR. "The Wrinkles of the City” (Şehrin Kırışıklıkları) Balat, İstanbul

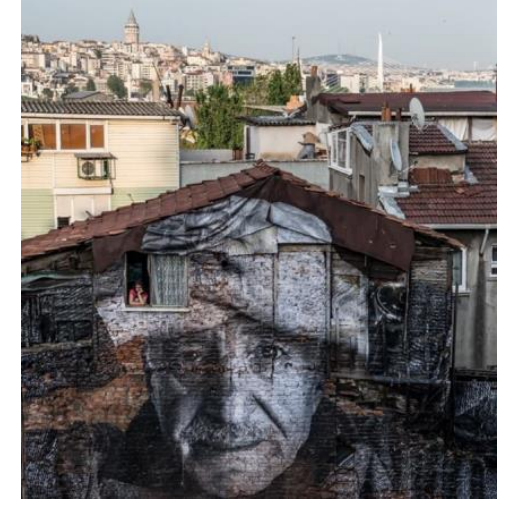

Kaynak: URL-4

Bu süreç Altıntaş ve Eliri’ ye göre (2012),

Günümüz kent yaşamının yoğunluğu göz önüne alındığında kamusal alanda sanat yapıtı kendine özgü güçlü bir etkiye ve yoğun bir tüketim ortamına sahiptir. Evlerimizin duvarında asılı duran resimlerden veya başköşemizde yerini bulan heykellerden çok daha etkin ve yoğun bir tüketim süreci söz konusudur (s.70)

Çağdaş sanatta 1960’lardan sonra, teknolojinin hızlı gelişimiyle pek çok disiplinin bir arada etkinliğini sürdürdüğünü söylemek mümkündür. Örneğin günümüz kamusal alanında heykel yeni açılımlara girerken, heykel dışında pek çok yeni plastik uygulama da toplumun görsel tüketimine sunulmaktadır. Bunlar arasında enstalasyonlara, performanslara, videolara, hatta ışıı gösterilerine bile rastlamak mümkündür. $\mathrm{Bu}$ anlamda galerilerden satın alınıp özel mekânlara taşınan sanat yapıtları ile kamusal alanlarda kendini gösteren sanat yapıtları arasındaki görsel tüketime dayalı fark dikkat çekicidir. Öyle ki sanat yapıtı bir meta olmanın dışına çıkmış, hatta kimi zaman geleneklere karşı çıkarak anlık tüketim sürecine girmiş, teşhir sırasında çekilen fotoğraflarla belgelenir hale gelmiş̧ir. Kamusal alan yapıtının anlık teşhiri, gösteri sanatlarının kavramsallığı ile bütünleşerek, performanslar, ışık ve lazer gösterileri, geçici enstalâsyonlar gibi pek çok disiplinin ortaya çıkmasına neden olmuştur (s.70)

Kentlerde kamusal ortak alanları yaratmak, kamusallı̆̆ üretmek, kenti yaratmaktır. "Sanat sosyal sınırları kaldırıcı ve dışlanmış insanların katılımını sağlayıcı bir araç da olabilir" (Yüksel, M. 2006).

Kamusal alanda gerçekleştirilmiş bir diğer örnek ise Mehmet Ali Uysal'ın "Ten" isimli eseridir (Şekil 5). Dünyanın eni iyi on kamusal sanat örneği arasına seçilen Mehmet Uysal'ın "Ten" isimli eseri ahşap, toprak ve çim tohumları kullanılarak gerçekleştirilmiştir.

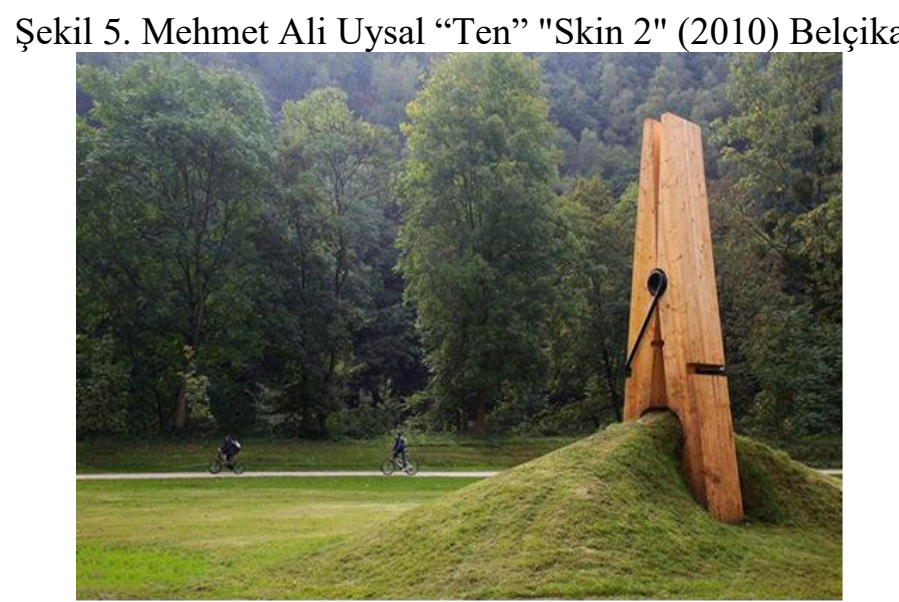

Kaynak: URL-5 
Eserlerinde mimari ve insan vücudundan esinlenen Uysal, günlük yaşamda kullandığımız nesneleri alışılmadık şekillerde ortaya koyarak bulundukları mekanın kendisine özgü dokusuyla bütünlük içinde ele almaktadır. Üzerine yerleştirildiği çim yüzeyle bütünleşmiş olan ahşap yapıt 'Ten', 'Mandal Heykeli' olarak da tanımlanmakta ve toplam beş edisyonu bulunmaktadır. Sanatçıya göre, eser yalnızca tahtadan oluşmuş değildir, aynı zamanda toprak ve çim tohumlarından meydana gelmektedir. Altı metre yüksekliğindeki dev kavramsal yapıt, 2010 yılından beri Belçika'nın Liege şehrindeki Chaudfontaine Park'ında bulunmaktadır. Uysal'ın eseri kamusal alan olan bir parkta sergilenerek alımlayıcı ile direkt bağlantı kurulabilmekte ve izleyici açısından özel bir çaba harcamadan sanat eseri ile şaşırtıcı bir etki altında karşılaşma olanağı sağlamaktadır.

Yaşadığımız mekanla aramızda hem zihinsel hem de bedensel bir ilişki söz konusudur. "Ev" ve "Konut" kavramları arasındaki farklar gibi. Evde belirli bir yaşanmışlık söz konusu; ama konut daha fiziksel bir tanım olarak karşımıza çıkmaktadır. Bir yerdeki yaşanmışlık oranın belleğini oluşturmaktadır. Mekanlar bir anlamda kayıt edici bir araç gibi her şeyi kendiliğinden kaydetmektedir. Mekanların belleği sanat eserleri aracılığı ile insanlara aktarılabilmektedir. Bunun birçok örneğini özellikle Sokak Sanatında (Street Art) ve sokak sanatçısı Banksy'in eserlerinde de görebilmekteyiz (Şekil 6).

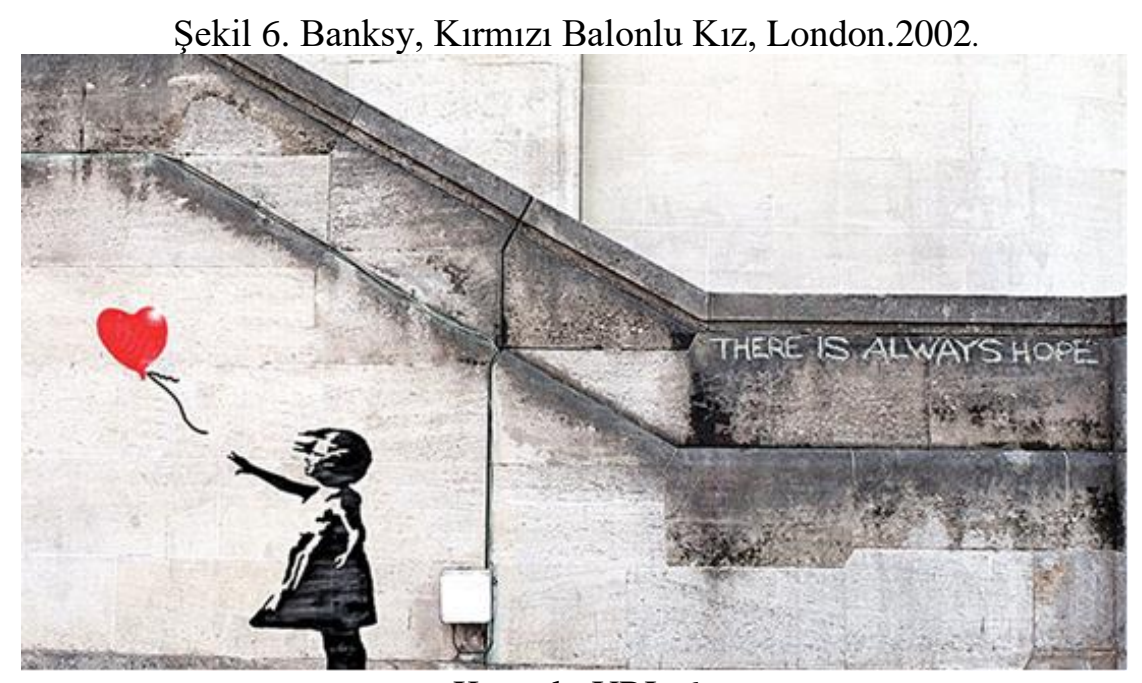

Kaynak: URL-6

Street Art terim olarak Jean-Michel Basquiat, Andy Warhol, Richard Hambleton gibi sanatçılar tarafından kullanılmıştır. Çoğu sanatçı reklamın egemenliğine bir başkaldırı olarak mekanlarını sokak olarak seçmiştir. Dünyanın önemli şehirlerinde Street Art ve Graffiti türünde eserler görmek mümkündür. Paris, Berlin, Londra, Tokyo, Barselona ve daha birçok şehirde önemli sanatçılar bu bağlamda çalışmalarına devam etmektedirler. Türkiye'de ise bu sanatsal hareketin yoğun olarak özellikle İstanbul'da ve son beş yılda daha çok geliştiği görülmektedir.

1985'lerde New York'ta kullanılmış olan bu terim, sokağı sanatsal yüzey olarak kabul eder. Birçok sanat alanından etkilenen, yerleştirme, geri dönüşüm, anlık eylemler gibi birçok türevi kapsayan, şehrin oluşturduğu platformu kullanarak ürünler veren anti-disipliner bir sanat akımıdır. "Şehirlerin mutsuz boş bina cephelerine, dev fabrika binalarına yapılan heybetli işler ise "mural" olarak adlandırılmaktadır" (Emlak Ansiklopedisi, 2013).

Son yıllarda dünyada ve Türkiye'de örneklerine sıkça rastladığımız grafiti kültürünün içinden kopup kendi yolunu çizen bir akım olarak karşımıza çıkmaktadır. "Street Art yani Sokak Sanatı, başka bir kavramsal karşılıkla Post-Graffiti olarak tanımlanmaktadır. 2013 yılında Londra'nın Brighton şehrinde karşılaşmış olduğum grafiti eserler Post-Grafiti kapsamında çalışmalar olarak değerlendirilebilir" (Şekil 7, 8) (Emlak Ansiklopedisi, 2013). 
Şekil 7. Grafiti, 2013, Brighton, London

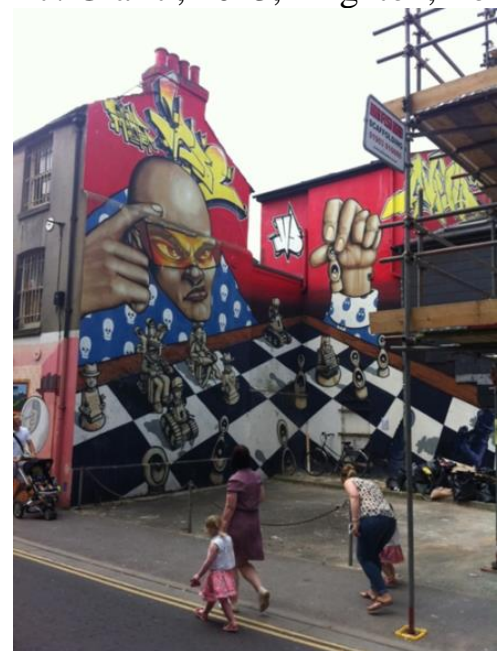

Kaynak: URL-7 (Kişisel Arşiv, 2013)

Şekil 8. Grafiti, 2013, Brighton, London.

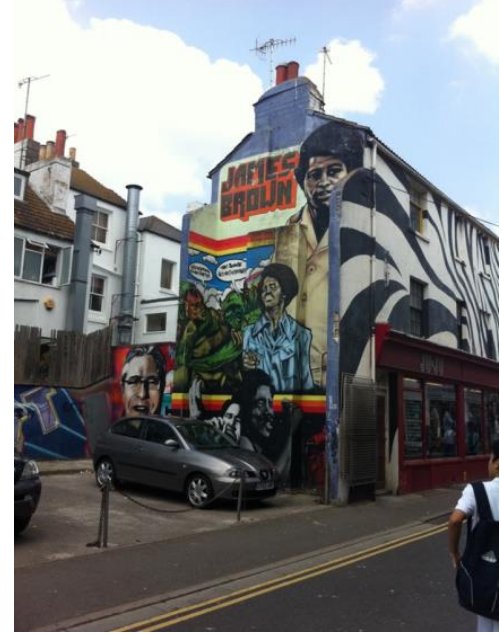

Kaynak: URL-8 (Kișisel Arşiv, 2013)

Kent dokusunun önemli bir parçası olan sokak ve kent meydanları, sanatın kent mekanlarında sergilenmesi açısından çeşitli olanaklar sunmaktadırlar. Sanat eserlerinin ve plastik ögelerin çeşitli biçimlerde ve halka açı alanlarda sergilenmesi izleyici ile yüz yüze gelmesini sağlamaktadır. Açık alanlarda çevreyle bütünleşen sanatsal çalışmalar, kentte eserlerin sergilenmesi için seri mekanlarına dönüşmekte adeta bir açı hava sergisi niteliği kazanmaktadır.

Kaldırım sanatı (Pavement Art) diğer sanat türlerine görece daha kısa bir tarihe sahip olsa da, günümüzde Edgar Mueller, Julian Beever ve Manfred Stader gibi dünya çapında tanınan birçok temsilciye sahiptir. Ancak sokak sanatını, klasik sanat teknikleri ve ilkeleriyle henüz 1980'li yıllarda birleştirmeye başlayan Amerikalı sanatçı Kurt Wenner, pastel boyalarla yaptığı üç boyutlu eserleriyle (Şekil 9) birçok açıdan bu sanat türünün öncüsü olarak kabul edilmektedir ve sanatını şu şekilde ifade etmektedir:

Resmi, heykel ve mimariyle birleştirirken, mevcut biçimlerin, tekniklerin ve malzemelerin sınırlarını zorlayarak ve bunları birbirleriyle yeni ilişkiler kurmaya zorlayarak, çoğu zaman bu üç sanat türünün arasındaki sınırları görünmez kılabiliyorum (Sanat Blog, 2011). 
Şekil 9. Kurt Wenner, Üç boyutlu sokak resimleri

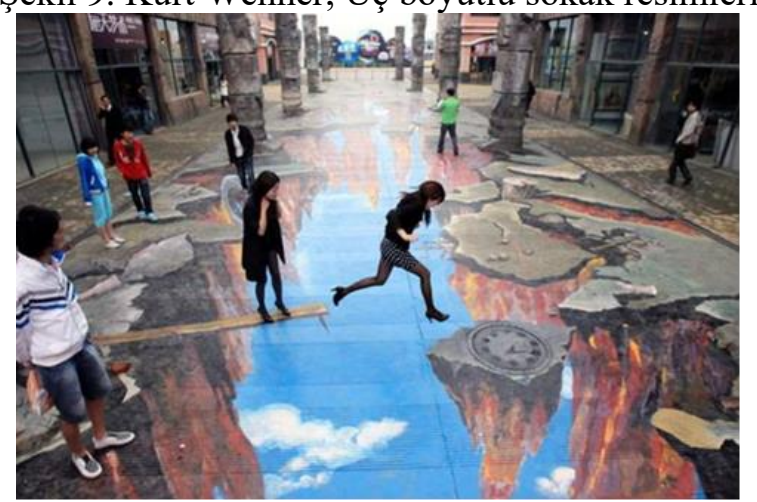

Kaynak: URL-9

Kurt Werner'in resimlerinde özellikle klasik Rönesans sanatından etkilendiğ görülmektedir (Şekil 10). Wenner, tarihi biçimsel bir zenginlik ve algısal illüzyonlar sağlayan mitolojiden, alegoriden, edebiyattan ve tiyatrodan aldığ 1 temaları kullanmaktadır.

"Mitoloji, alegori, edebiyat ve tiyatrodan öğeler ödünç aldığım için, benim resimlerim birçok sanat geleneğinin keşfi için birer davetiyedir. Resimleri görenler oradaki hikayenin kaynağını çıkaramasalar da orada bir hikaye olduğunu hissederler ve bu da meraklarını uyandırır" (Sanatblog, 2011).

Şekil 10. Kurt Wenner, Babil, 2007, Üç boyutlu sokak resimleri

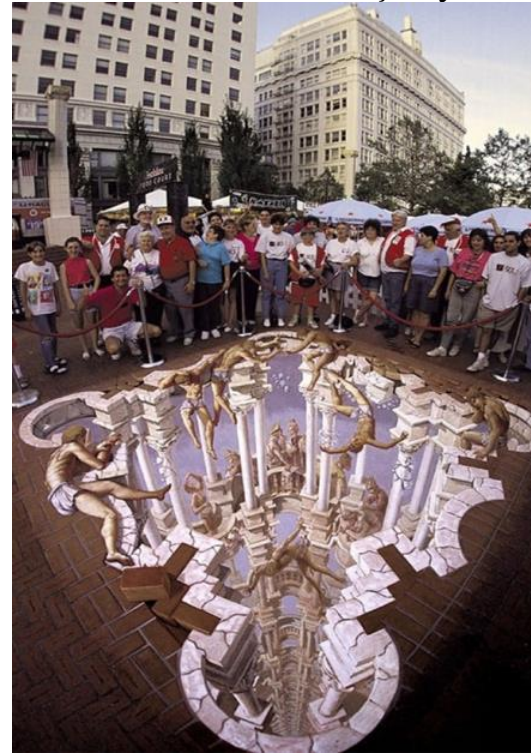

Kaynak: URL-10

Mekanların düzenlenişinde estetik kaygıların öne çıkması ile bireylerin mekanla ilişkisinin yaratıcı bir noktaya taşındığı ve bu mekanlardaki eylemliliklerin mekana göre şekil aldığ1 göz önünde tutulduğunda; mekan içinde varolan nesneler, biçimi ve renkleri ile mekanda bulunan bireyleri uyarmakta, sorgulatmakta ve düşündürmektedir. Kamusal alanlarda yer alan nesnelerin birey üzerindeki etkinliği düşünülürse, toplumsal yaşam alanlarına sanat öğesinin sokulması gereği gündeme gelmektedir (Öztürk, 2007, s. 46).

Sanatçıların çevreye olan duyarlılıkları, mekanları daha yaşanabilir kılmakta ve mekana yeni bir kimlik kazandırma çabalarının da göstergesi durumundadır. Alımlayıcıyı sanatsal etkinliğe davet eden nitelikte olan bu yaklaşım, toplumsal hareketlerin belirleyicisi hatta yön vereni olabilmektedir. 
Sanat yapıtı, alımlayıcı tarafından izlenmesi gereken bir olgudur. Sanat yapıtının var olma amac1, izleyici tarafından alımlanmayı gerektirir. Böylece sanat, insan topluluklarını niteliksiz bir yığın olmaktan çıkarak estetik değerlerle donatılmış nitelikli bireylerden oluşan toplumsal bir varlığa dönüştürmenin en iyi yollarından biridir. Bu nedenle sanatçılar eserlerini tasarlarken onların nerede sergilenmesi gerektiğini, hangi ölçülerde olması gerektiğini de doğal olarak hesaba katmaktadır. Eserin kamusal bir alanda, bir meydanda ya da bir sokakta nasıl biçimleneceğini de öngörmekte ve çalışmalarını bu doğrultuda yapmaktadırlar. Bu noktada kamusal sanatta öne çıkan ana unsurlar; mekansal kaygılar, sanatçının sanatsal yaklaşımı ve alımlayıcı tepkilerinden oluşmaktadır. Sanatçı eserini kurgularken izleyiciyi de şaşırma, korkma, farkındalık oluşturma, vb. gibi etkilerle alımlayıcıyı merkeze alarak hareket edebilmektedir.

Kamusal sanat eserlerinin birçoğu dayanıklı malzemelerden üretilirken bazıları birkaç saat sonra yok olacak biçimde tasarlanmaktadır. Sanatçı tarafından eserin kalıcı olmasından daha önemli olan şey, kamusal yaşamda tüketilmesi ve eserin görsel mesajının izleyiciye doğrudan ulaşması olabilmektedir. Mevcut yaşam akışı içinde insanlar belli rutinleri yaşayarak kent içinde hareket etmektedir. Bu rutinleri bozacak olan ve kent yaşamına hareket ve devinim kazandıracak olan şey sanatın kentin tüm hücrelerine nüfuz etmesi ile mümkün olacaktır. Sanatı insanın dışında değil, insanı sanatın içinde var edecek bir yaklaşım çağın ruhunu da yansitmaktadır (Öztürk, 2007, s. 46).

Kamusal alanda tüketilen sanat eserleri birlikte olma duygusunu güçlendirmektedir. Birlikte olma durumu en güçlü biçimde kamusal alanlarda yaşanmaktadır. İspanyol sanatçı Jaume Plensa'nın 'Together'/'Birlikte' isimli yerleştirmesi 2015 yılında düzenlenen Venedik Bienalinde, San Marco meydanının karşısında yer alan adadaki St. Giorgio Maggiore kilisesinde yer almıştır. Kilisenin içindeki iki heykel (askıda duran bir el ve merkeze yerleştirilmiş insan başı) karşı karşıya durmaktadır ve aralarındaki etkileşime kiliseyi gezenleri de dahil etmektedir (Şekil 11, 12).

Kilise mekanlarına varıncaya kadar kamusal alanlarla sanat eserlerinin sergileniyor olması, günümüzde sanat anlayışının mekan kavramına bakışındaki yeni açılımların bir göstergesi olarak karşımıza çıkmaktadır. Mekan algımızı değiş̧irecek güçteki bu yaklaşımlar geleceğin sanat anlayışı hakkında da bize ipuçları vermektedir.

Şekil 11. Jaume Plensa, "Birlikte", 56.Venedik Bienali, Basilica San Giorgio Maggiore, Isola di San Giorgio Maggiore, 2015

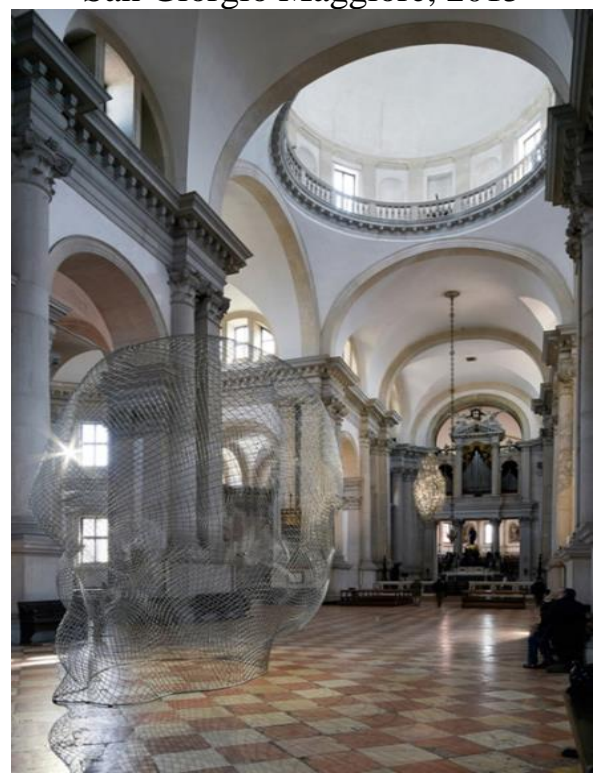

Kaynak: URL-11 
Şekil 12. Jaume Plensa, "Birlikte”, 56.Venedik Bienali, Basilica San Giorgio Maggiore, Isola di San Giorgio Maggiore, 2015

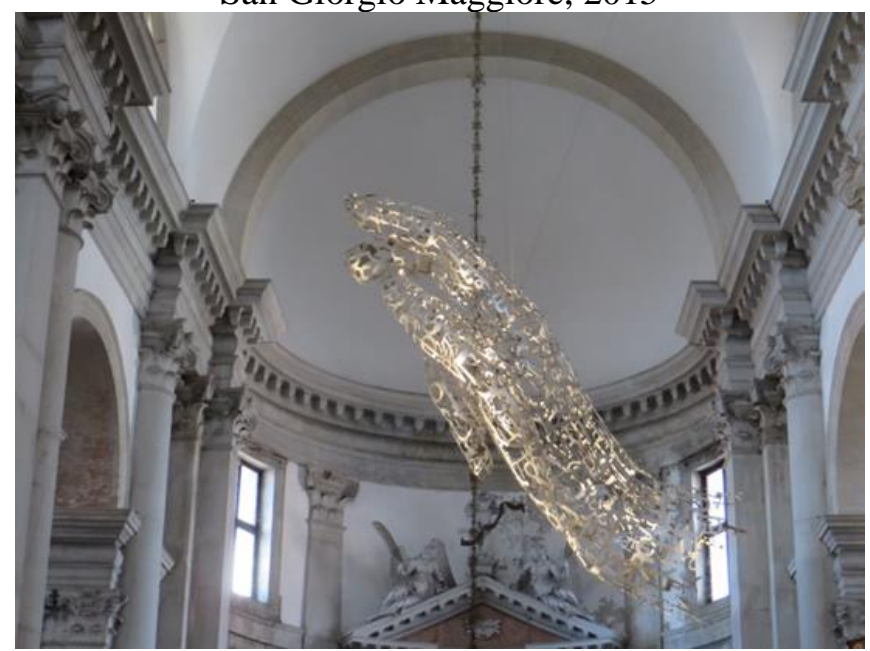

Kaynak: URL-12

Sanatçılar, tahayyül güçleri ile içinde yaşadıkları çevreyi, yaşam alanlarını sanat eserine dönüştürmeye, eserlerini insanlarla paylaşmaya, insanları sorgulatan, eleştiren bireyler olmaya zorlamaya devam edeceklerdir. Günümüz ileri teknolojisi ve sanatının sınır tanımaz niteliği, geleceği şekillendiren sanatçıların yaşamın tümünü sanat platformuna dönüştürecek güce sahip olduğunu da göstermektedir.

\section{Sonuç ve Öneriler}

Kavramsal sanatın ortaya çıkmasıyla birlikte, bugün sanatı tanımlarken estetik kaygıların yanı sıra, eleştirel bakış açısı geliştirmek ve görünür kılmak gibi işlevler de öne çıkmaktadır. Sanat ve çevre, yani kamusal alanda sanat düşüncesi içerisinde bu işlevlerin, sanat yapıtları aracılığıyla izleyicisiyle birebir etkileşimde olmasından dolayı kendi bağlamları dışında da söylemler gerçekleştirdikleri görülmektedir. Yine bu düşünce, yapıtların sadece 'beyaz küp' olarak ifade edilen izole edilmiş galeriler ve müzeler gibi sanat mekanlarından dışarı çıkışının da göstergesi olmuştur. Böylece insanlar sanat eserlerine çok çaba harcamadan ulaşabilmektedirler.

Sanat yapitının alımlayıcı tarafindan izlenmesi kadar alımlayıcının esere kolay bir biçimde ulaşılabiliyor olması da önemlidir. Kamusal sanat, bunu en iyi biçimde gerçekleştiren sanatsal tavırlardan biri olarak ifade edilebilir. Sanatsal kaygıların ve aktarılan fikrin yanı sıra, izleyicinin aktif bir biçimde bu etkileşim sürecine dahil olmasını da olanak sağlamaktadır. Bu etkileşim süreci kamusal diyaloğun, farkındalığın ve sanata verilen değerin artmasını sağlamaktadır.

Kamusal sanat, son yıllarda artan oranda ve yaygın biçimde sanatsal üretim alanı olarak görülmektedir. Bu durum 1960'li yıllardan bu yana yoğun biçimde dünyanın her yerinde görülebilmektedir. Mekan-sanatç1-izleyici ilişkisi bağlamında eserlerin oluşum süreci, yeni öneriler sunmaya ve birbirlerini etkilemeye devam etmektedir. Günümüzde kamusal alanda oluşan ya da sergilenen sanat eserleri, hayatın içinde olmaya, herhangi bir ayrım gözetmeksizin bütün bireylerin ulaşabileceği mekanlarda, bireylerin etkin bir biçimde eseri deneyimlemesini teşvik ederek varlıklarını devam ettirmektedirler. Kamusal sanatın amacı; bireyleri çevresinde gerçekleşen olayları, ilişkileri ve çeşitli olguları pasif izleyen olmaktan çıkararak, sürece katılan, eserle aktif uyum içinde bir farkındalık oluşturmaktır.

Sanat toplumsal birlikteliği destekleyen ve katkı sunan yapısı ile toplumsal sorunları iyileştiren, rutin hayatı dönüştürmeye olanak sağlayan, toplumsal yaşamı aktif, yaratıcı dinamiklerle besleyen bir vazgeçilmez olarak karşımıza çıkmaktadır. Ayrıca sanat, sosyal 
sınırları aşan niteliği ile sosyal yaşamdan uzaklaşmış, yabancılaşmış, kırsal bölgelerde yaşayan, sanat merkezlerine uzak kalmış bireylerin, aktif hale gelmesini, sosyal yaşama aktif bir uyumla katılmasını sağlayan bir araç olarak da görülebilir. Kamu alanları, insan ilişkilerinde birliktelik duygusunu geliştirirken ortak bilinçaltını da oluşturmaktadır. Örnek olarak camiler, kiliseler, müzeler, opera binaları, sinemalar, üniversiteler ve kütüphaneler bu bilincin oluşmasına neden olan mekanlar olarak karşımıza çıkmaktadır. Kamusal kültürün oluşumu hem sosyal ilişkilerin hem de kentin görsel algısını inşa etmeyi kapsamaktadır.

Kamusal alanda sanat eserlerinin insanlarla iç içe olması, sanat eserinin toplumsallaşmasını da vurgulamaktadır. Bu durum bizlere aynı zamanda çağdaş bir kent tasarımında kent yöneticilerinin sanata desteğinin ve sanatçılarla işbirliğinin son derece önemli ve gerekli olduğunu da göstermektedir. Geleceğin kentlerinin sanatla şekillendirilmesi, hem bireylerin mutluluğu hem de toplumsal barış ve huzurun sağlanmasında önemli katkılar sunacaktır. Bu katkılar, kamusal mekanların insanların sosyal, psikolojik, estetik değerlerini içeren ihtiyaçlarını karşılaması ile mümkün olmaktadır. Kent dokusuyla uyumlu, doğayla bütünleşen sanat eserleri, mekanları daha yaşanabilir hale getirirken aynı zamanda insanların duyarlılıklarını, algılarını ve farkındalıklarını geliştirmektedir. Çevreye duyarlılığ gelişmiş olan bireyler, toplumsal duyarlılı̆̆ın temel yapı taşlarıdırlar. Kamusal sanat, kamusal konuları içeren bir sanatsal yaklaşım olması nedeni ile çevre kültürüne eleştirel bakışı da içinde barındırmaktadır. Eleştirel yaklaşım interaktif bir biçimde kendimizi ve çevremizi yeni bir bilinçle algılamamızı sağlarken, ortak değerlerin paylaşımına olanak tanımaktadır. Farklı kültürlere saygı ve onların var olma hakları üzerinde diyalog ortamı ve iletişim ağı oluşturmaktadır.

21.yüzyılda teknolojik ilerlemenin getirdiği yeni olanaklar ve yeni ifade biçimlerini kullanan günümüz sanatçıları, mekan ile olan ilişkisine yeni açılımlar getirmiş, sanatı ve estetiği güncel verilerle besleyerek alternatif kamusal alanlar ve alternatif mekan algiları geliştirmişlerdir. Buna en iyi mimari örnek, mimar Emre Arolat tarafindan, 2014 yılında İstanbul Büyükçekmece'de yapılan Sancaklar Camii'dir. Cami, İslam felsefesi ile uyumlu, mütevazı, sade bir o kadar da etkili mimarisi ve mekanda gün ışığının sıra dışı kullanımı ile insanların alışık olduğu geleneksel cami mimarisi ve mekan algısını tamamen değiştirecek güce sahip bir eserdir. Farklı kültürlerden ve inançlardan insanların ziyaret ettiği bir mekan olarak insanların dikkatini çekmekte ve çok fazla sayıda insanın ziyaret ettiği bir mekan haline dönüşmektedir (TRT Haber, 2018). Bu örnekte olduğu gibi kamusal mekan algısını değiştiren projeler bireyin mekanla olan ilişkisini değiştirmekte, mekanların sahiplenilmesine ve çevre algısının olumlu yönde etkilenmesine neden olmaktadır. Kalabalık ve gürültülü kent yaşamının karmaşasından uzak huzurlu, sakin atmosferlerin oluşturulduğu kamusal mekanlar insanların kendilerini iyi hissetmesine neden olmaktadır.

Kamusal alanlarda toplumla etkileşime geçmeyi amaç edinen projelerle, toplumun her kesiminden insanın sanatla buluşması hedeflenmektedir. Kamusal sanat ve toplum merkezli sanatsal projelerin hayata geçirilmesi ile insanların farklı yaşamsal deneyimlerini artırdıkları gözlemlenmektedir. Özellikle son yıllarda gerçekleşen sanatsal projelerle gerek tema açısından gerekse estetik açıdan, kamusal mekanlarda karşılıklı anlayış, hoşgörü ve saygı temeline dayalı bir barış toplumunun oluşmasının hedeflemekte olduğu görülmektedir. Bu durum bir araç olarak düşünüldüğünde, kamusal alanda sanata verilen değerin geliştirilmesinde de önemli aşamalar kat edilmektedir.

Kamusal sanat aracılığı ile kamusal kültür yaratmak, sosyal etkileşim için kamusal mekanların biçimlendirilmesi ve kamusal mekanların görsel yeniden inşası sağlanmış olacaktır. Çağdaş sanatın en önemli açılımlarından olan Arazi Sanatı (Land Art), Performans Sanatı, Çevresel Sanat gibi sanatsal ifade biçimleri, yapıtın galerilerden çıkarak günlük hayatın pratiklerinin içine dahil olmasının alt yapısını hazırlamışlardır. Dünyanın tüm metropollerinde kamusal alanlar; sokaklar, caddeler, kamu binaları, üniversite kampüsleri, meydanlar sanat eserlerinin sergilendiği alanlar olarak kamusal sanatın mekanları haline gelmiştir. Çalışmanın en 
önemli bulgularından biri; 14. İstanbul Bienali örneğinde olduğu gibi 545.000 kişinin etkinliği izlemiş olması, kamusal alanlarda sergilenen sanat eserlerinin özel mekanlara oranla daha çok izleyici kitlesi ile buluşması ve bu nedenle bireyle etkileşiminin en yüksek düzeyde olması sonucudur.

Mevcut yaşam alanları, insanların gereksinimlerini tam anlamıyla karşılayamadığından yaratılmış mekanik çevre bireyi olumsuz yönde etkilemektedir. Bireyin üretken, dinamik ve yaratıcı süreçlere geçişi aşısından kamusal alanlarda sanat yapıtı ve estetik tasarımlarla buluşması bu olumsuz etkilerin azalmasına katkı sağlamaktadır. Kamusal alanda sanat eseri; paylaşma, katılım, etkileşim ve iletişim süreci yaratarak toplumsal sorumluluğun temellerini atmaktadır. Kamusal sanat, toplumsal duyarlılıkların, kamusal diyaloğun ve farkındalıkların gelişimine önemli katkılar sağlayarak demokratik bir iletişim ve paylaşım alanı yaratmaktadır.

\section{Kaynakça}

Altıntaş, O. ve Eliri, İ. (2010), Birey Toplum İlişkisinde Kent Kültürü, Kamusal Alan Ve Onda Şekillenen Sanat Olgusu. Ídil Dergisi, 1(5), 61-74. doi: 10.7816/idil-01-05-05

Berger, J. (2010). Görme Biçimleri (Y. Salman, Çev.). (16. Baskı). İstanbul: Metis Yayınları.

Emlak Ansiklopedisi, (2013). Street Art nedir? Sokak sanatı nedir?, http://emlakansiklopedisi.com/wiki/street-art-nedir-sokak-sanati-nedir, Erişim tarihi: 01.03.2020.

Habermas, J. (1962). Strukturwandel der Öffentlichkeit, Untersuchungen zu einer Kategorie der bürgerlichen Gesellshaft. Neuwied: Hermann Luchterhand Verlag.

Habermas, J. (2001). Iletişimsel Eylem Kuramı. (M. Tüzel, Çev.) İstanbul: Kabalcı Yayınları.

Habermas, J. (2003). Kamusallı̆̆ın Yapısal Dönüşümü, ( Bora,T. Sancar, M. Çev.). (5. Baskı). İstanbul: İletişim Yayınları.

İrvan, S. (Der.). (2002). Medya, Kültür, Siyaset. (2. Bask1). Ankara: Alp Yayınevi.

Keane, J. (2002). 'Kamusal Alanın Yapısal Dönüşümleri' Medya Kültür Siyaset. Derleyen S.İrvan, Ankara: Alp Yayınevi.

Koçan, G. (2008). Models of Public Sphere in Political Philosophy, EUROSPHERE, Çevrimiçi çalışma makaleleri.No.02. http//eurosphere.uib.no/knowledgebase/workingpapers.htm (Erişim tarihi: 01.03.2020).

Mutlu, E. (2004). Illetişim Sözlü̆ğü. (4. Baskı). Ankara: Bilim ve Sanat Yayınları.

NTV Sanat Haberleri (2015). 14. İatanbul Bienali'nde tuzlu suyu keşfedin, https://www.ntv.com.tr/sanat/14-istanbul-bienalinde-tuzlu-suyukesfedin,wIGJtluDRkuhFlkseZwxtw (Erişim tarihi: 01.03.2020).

Öztürk, Ö. (2007). Kentsel Kimlik Oluşumunda Güzel Sanatların Yeri: İzmir Örneği (Yayımlanmış Yüksek Lisans Tezi). Ankara Üniversitesi, Ankara.

Pustu, Y. (2006). Küreselleşme Sürecinde Kent “Antik Site'den Dünya Kentine”. Sayıştay Dergisi, 17(60), 129-151. https://jurix.com.tr/article/9468 (Erişim tarihi: 09.12.2020).

Sanatblog, (2011). Kurt Wenner: Sokakta $\ddot{U} c ̧$ Boyutlu Klasik Sanat. http://www.sanatblog.com/sokakta-klasik-sanat/ (Erişim tarihi: 01.03.2020).

Sanatblog, (2015). Jr Istanbul'da: Şehrin Kırışlklıklarl. http://www.sanatblog.com/jristanbulda-sehrin-kirisikliklari/ (Erişim tarihi: 01.03.2020).

Sennett, R. (2002). Kamusal İnsanın Çöküşü. (Durak, S. Yılmaz, A. Çev.). İstanbul: Ayrıntı Yayınları. 
Sheilk, S. (2005), Anstelle der Öffentlichkeit? Oder: Die Welt in Franfmenten, (Kamusal Alanın Yerine Ne mi? Ya da, Parçalardan Oluşan Dünya), Kritik der Kreativiat, yay. Haz. Gerald Raunig ve Ulf Wuggenig, Viyana.

Tansuğ, S. (1982). Herkes İçin Sanat. İstanbul: Altın Kitaplar Yayınevi.

TRT Haber, (2018). Ödüle doymayan modern yeraltı camisi: Sancaklar Camii. https://www.trthaber.com/haber/turkiye/odule-doymayan-modern-yeralti-camisi-sancaklarcamii-366762.html (Erişim tarihi: 10.012.2020).

Tunalı, İ. (1996). Estetik. İstanbul: Remzi Kitabevi.

Yüksel, M. (2006). Kamusal Alanda Sanat. 4. Uluslararası H. Gezer Taş ve Beton Heykel Sempozyumu, Mersin Üniversitesi, Mersin.

URL-1: $\quad$ https://www.ntv.com.tr/sanat/14-istanbul-bienalinde-tuzlu-suyu kesfedin,wIGJtluDRkuhFlkseZwxtw (Erişim tarihi: 01.03.2020).

URL-2: $\quad$ https://www.ntv.com.tr/galeri/seyahat/chicagonun-bulut-kapisinaturistilgisi,kx6AKJZwb0O6Yx5E_RI0yw/Nw729NnVrUS_Y31JPNPPIQ (Erişim tarihi: 05.03.2020).

URL-3: http://bonpurloryan.com/2015/05/24/unlu-sokak-sanatcisi-jr-sehrin-kirisikliklari-icinistanbulda/ (Erişim tarihi: 05.03.2020).

URL-4: http://bonpurloryan.com/2015/05/24/unlu-sokak-sanatcisi-jr-sehrin-kirisikliklari-icinistanbulda/ (Erişim tarihi: 05.03.2020).

URL-5: http://www.mandalsanat.com/mehmet-ali-uysal/ (Erişim tarihi: 05.03.2020).

URL-6: http://www.themagger.com/duvarlarin-efendisi-banksy/ (Erişim tarihi: 05.03.2020).

URL-7: Kişisel Arşiv, 2013.

URL-8: Kişisel Arşiv, 2013.

URL-9: http://www.kisiselgelisimveolumlamalar.com/resim-sanati/kurtwenner-sokak-tablolarit709299.0.html (Erişim tarihi: 01.03.2020).

URL-10: http://www.sanatblog.com/sokakta-klasik-sanat/ (Erişim tarihi: 01.03.2020).

URL-11: http://www.artfulliving.com.tr/edebiyat/venedik-bienalinde-edebiyatin-izini-surmek-i3821 (Erişim tarihi: 05.03.2020).

URL-12: http://entrevoirart.blogspot.com.tr/2015/06/together-jaume-plensa.html (Erişim tarihi: 05.03.2020).

ETIKK ve BİLIMSEL İLKELER SORUMLULUK BEYANI

$\mathrm{Bu}$ çalışmanın tüm hazırlanma süreçlerinde etik kurallara ve bilimsel atıf gösterme ilkelerine riayet edildiğini yazar(lar) beyan eder. Aksi bir durumun tespiti halinde Afyon Kocatepe Üniversitesi Sosyal Bilimler Dergisi'nin hiçbir sorumluluğu olmayıp, tüm sorumluluk makale yazarlarına aittir. 